\title{
The Moderating Roles on the Relation between Internet Addiction and Burnout
}

\author{
Halil Özcan Özdemir \\ Ahi Evran Üniversitesi, Kırşehir \\ hoozdemir@ahievran.edu.tr \\ ORCID ID: https://orcid.org/0000-0002-0021-3618 \\ Hüsnüye Neşe Arslan \\ Ahi Evran Üniversitesi, Kırşehir \\ nesearslan@ahievran.edu.tr \\ ORCID ID: https://orcid.org/0000-0002-2582-7683
}

Araștırma Makalesi

Geliş Tarihi: $12.03 .2018 \quad$ Revize Tarihi: $12.06 .2018 \quad$ Kabul Tarihi: 21.06 .2018

\section{Attf Bilgisi}

Özdemir, H. Ö. ve Arslan, H. N. (2018). The moderating roles on the relation between internet addiction and burnout, Ahi Evran Üniversitesi Sosyal Bilimler Enstitüsü Dergisi, 4(1), 31-41. Doi: 10.31592/aeusbed.404411

\begin{abstract}
In accordance with evolutionary improvements in technology, today new technological illnesses developed, one of them being internet addiction. Different from the literature on gender, there are only a few studies on the relationship between internet addiction and the educational level. The aim of the present study is to explore the moderating role of gender and level of education on the relation between internet addiction and burnout of future leaders studying at the university level. The data was conveniently collected from 233 students enrolled in the Business and Administration Department in the Faculty of Economics and Administrative Sciences and the Vocational School of Social Sciences in a Turkish university. The instruments of the study were used the originally named "Skala zur Erfassung der Internetsucht" internet addiction questionnaire, and the Maslach Burnout Inventory - Student Survey (MBI-SS). The results of the study revealed a positive and significant relationship between internet addiction and burnout. However, the variables of gender and educational level were found to have no moderating role in the correlation.
\end{abstract}

Key Words: Internet addiction, burnout, social media, entrepreneurship

\section{İnternet Bağımlılığı ve Tükenmişlik Arasındaki İlişkide Düzenleyici Roller}

\section{$\ddot{\mathrm{Oz}}$}

Teknoloji alanındaki evrimsel gelişmelere uygun olarak, günümüzde internet bağımlılığı olan yeni teknolojik hastalıklar gelişmiştir. Toplumsal cinsiyet literatüründen farklı olarak internet bağımlılığı ile eğitim düzeyi arasındaki ilişki hakkında sadece birkaç çalışma bulunmaktadır. Bu araştırmanın amacı; üniversite mezunu olacak girişimci adaylarının internet bağımlılık düzeyleri ile tükenmişlikleri arasındaki ilişkide cinsiyet ve öğrenim düzeyinin düzenleyici rollerinin belirlenmesidir. Araştırmanın verileri bir Türk devlet üniversitesindeki İktisadi ve İdari Bilimler Fakültesi İşletme bölümü ile Sosyal Bilimler Meslek Yüksekokulu İşletme programında öğrenim gören 233 öğrenciden rastgele seçim yöntemi ile toplanmıştır. Araştırmada veri toplama aracı olarak orijinal adı "Skala zur Erfassung der Internetsucht" olan internet bağımlılığı ölçeği Maslach Tükenmişlik Envanteri-Öğrenci Formu (MTE-ÖF) kullanılmıştır. Araştırma grubundan elde edilen veriler SPSS 22 istatistiksel paket programı ile analiz edilmiştir. Analiz sonucuna göre; internet bağımlılı̆̆ ile tükenmişlik arasında pozitif yönlü bir ilişki olduğu; bu ilişkide cinsiyet ve öğrenim düzeyi faktörlerinin düzenleyicilik rolünün olmadığı tespit edilmiştir. Araştırma bulguları yorumlanmış ve daha sonra gerçekleştirilecek araştırmalara yönelik öneriler geliştirilmiştir.

Anahtar Kelimeler: İnternet bağımlılı̆̆ı, tükenmişlik, sosyal medya, girişimcilik

\section{Introduction}

The areas of internet use have extended profoundly in the last two decades leading to an increase in a variety of websites used for communication, trading, banking facilities and entertainment, particularly the most prominent ones such as Twitter, Facebook, Instragram and WhatsApp. The reasons for this growth can be listed as the internet's easy access without being limited to time and space and its providing of effortless and fast interaction through obtaining and sharing information. 
Thanks to these elements, the internet is the most fundamental and captivating technological innovation of our era. Thanks to its endless possibilities, it has become one of the most treasured instruments.

In accordance with evolutionary improvements in technology, today new technological illnesses developed, one of them being internet addiction. The concept of internet addiction was originally used by Goldberg (1996) in his book "The Diagnostic and Statistical Manual of Mental Disorders" which included categories related to internet addiction (Eroğlu and Bayraktar, 2017). Internet addiction has been divided into four elements: excessive use, tolerance, withdrawal and negative social repercussions (Block, 2008). The need to socialize quickly and efficiently at any time and place is considered as an important factor in internet addiction (Douglas et al., 2008). The desire of taking on roles and personalities which are different from the real self and the easiness of sharing thoughts and opinions are some of the reasons that make the internet more appealing (Cengizhan, 2005; Eroğlu and Bayraktar, 2017). Furthermore, people find the chance to experience emotions and passion in the virtual world which they cannot experience in the real world (Batem, 2016).

The number of people who suffer from extensive internet usage gradually increase all around the world, including Turkey where internet addiction is treated as a severe illness. The recent report of the Turkish Statistical Institution (2017) revealed that $66.8 \%$ of the population uses the internet, which may be considered as a low rate. However, it was also reported that $93.8 \%$ consider themselves as regular users and $87.9 \%$ use the internet almost every day. Examining the age range of these users, it was noted that the highest level of internet usage was between the ages of 14 and 24, clearly indicating an extensive use among the youth (TurkStat, 2017). As a result of these statistics, it is fortunate that in 2012 an internet addiction polyclinic at the Bakırköy psychiatric hospital was opened (Özdemir, 2017).

Different from the concept internet addiction, closely akin definitions exist on burnout. According to Freudenberger (1974) burnout is "the loss of power and energy resulted from failure, exhaustion and overloading or the depletion of internal resources resulted from unmet needs (cited in Ar1 and Bal, 2008). Maslach defines burnout as a prolonged psychological syndrome that shows up in response of stress boosting factors at the workplace. The concept burnout is divided into and analyzed under three components, being emotional exhaustion, depersonalization and reduced personal accomplishment (Maslach and Jackson, 1981). Although research on burnout started with the analysis of workers and businessmen, a fair amount of studies exists on the burnout student's experience (Yang and Cheng, 2005; Zhang, Gan and Cham, 2005). Even though being neither a business owner nor a worker, the effort and time spent at school is accepted as work, which inevitably leads to crucial similaritites between staff burnout and student burnout (Schaufeli et al., 2002; Zhang, Gan and Cham, 2005). Thus, the analysis of students' level of burnout may have a predictive value of the level of burnout they might have in the future as office workers or entrepreneurs.

\section{Literature Review and Hypotheses}

\section{Internet addiction and burnout}

As the present study, a considerable number of studies explored the factors influencing internet addiction (Hawi, 2012; Tsitsika et al., 2014) and burnout separately; however, only few analyzed the relation between these two concepts. Avci and Şahin (2017) revealed in their study a significant relationship between internet addiction and the sub-categories of burnout. In a similar vein, SalmelaAro et al. (2017) stated as a result of their study that extensive internet usage can lead to study burnout and develop other depressive symptoms.

The literature yields contradictive results on the role of gender in relation to internet addiction. Some studies claimed significant differences in internet addiction between the genders and added that males are more likely to be addictive than females (Mottram and Fleming, 2009; Randler et al., 2014). On the other hand, other numerous studies declared that the genders have different degrees of internet addiction, but are not significantly different (Turan, 2015; Lam et al., 2009; Subrahmanyam and Lin, 
2007; Bayraktar and Gün, 2007; Anin et al., 2017). In the study of Şahin et al. (2016), it was found that the female participants had a higher degree of internet addiction than the male participants. Nonetheless, they added that the statistical analyses revealed no significant difference between the degrees of internet addiction of the female and male students. On the other hand, Akdağ et al. (2014) and Kır and Sulak (2014) asserted that gender is a fundamental determinant in the development of internet addiction. Contrary to the study of Şahin et al. (2016), their analyses reached the result that male students have a higher level of internet addiction than female students. In the same study, Şahin et al. (2016) also looked at possible differences of internet addiction among the freshman, sophomore, junior and senior students. The findings showed that the freshman students have a higher level of internet addiction than the senior students. Despite the difference of level of internet addiction between the freshmen and seniors, this difference was not found to be significant.

Similarly, there are no definite results on the relation between gender and burnout; moreover, the literature holds very contrasting findings. The studies of Sucuoğlu and Kuloğlu (1996) and Işıklar (2002) revealed that gender has no effect on the level of burnout. Furthermore, some studies claim that male students have a higher rate of burnout (Girgin, 1995), while others reported to have found that female students are more burned out (Tümkaya, 1996; Gündüz et al., 2012). Due to these contradictive studies, it would be appealing to examine the relationship between internet addiction and in the Turkish context and among university students.

Different from the literature on gender, there are only a few studies on the relationship between internet addiction and the educational level. One of these studies was done by Lee (2009) who revealed that no statistically significant difference was found between the four school years.

The present study explores the following hypotheses;

Hypothesis 1: Is there a significant relationship between internet addiction and burnout?

Hypothesis 2: Does the educational level have a moderating role in the relationship between internet addiction and burnout?

Hypothesis 3: Does gender have a moderating role in the relationship between internet addiction and burnout?

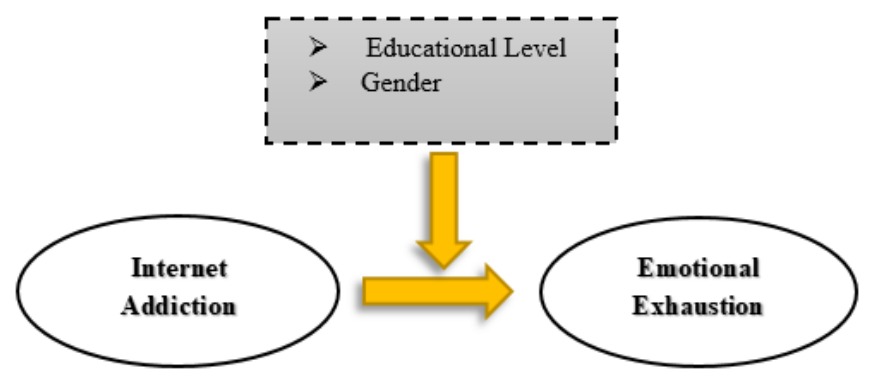

Figure 1. The theoretic design of the study

In this model, the independent variable was identified as internet addiction, the dependent variable was emotional burnout, and the moderating variables were the level of education and gender.

\section{Method}

The present study was administered on 233 Business and Administration students in the Faculty of Economics and Administrative Sciences and the Vocational School of Social Sciences at a Turkish university. The instruments of the study were the originally named "Skala zur Erfassung der Internetsucht" internet addiction questionnaire designed by Hahn and Jerusalem (2001) and translated into Turkish by Şahin and Korkmaz (2011), and the Maslach Burnout Inventory - Student Survey (MBI-SS) designed by Schaufeli et al. (2002) and translated into Turkish by Çapri, Gündüz and Gökçakan (2011). The Statistical Package of Social Sciences (SPPS) 22 was used for the statistical 
analyses. The data was collected using convenience sampling to reach student participants. Convenience sampling is within the non-probability sampling design which is widely accepted in sociological research when the primarily aim of the study is to analyzed the sample explorative or descriptively (Atkinson and Flint, 2001).

\section{Findings}

The findings and clarifications of the proposed hypotheses are stated as the following.

Table 1

Correlation between internet addiction and burnout

\begin{tabular}{lcccc}
\hline Variables & Mean & $\mathrm{S}^{2}$ & $\mathrm{IA}$ & $\mathrm{B}$ \\
\hline \multirow{2}{*}{ Internet Addiction } & 2,05 & 0,579 & - & $0,450^{* *}$ \\
Burnout & 3,00 & 0,370 & $0,450^{* * *}$ & - \\
& & & &
\end{tabular}

After the analysis of the answers in the questionnaire, it was revealed that the participants had a medium level of internet addiction with the most answers to the internet addiction items given as "little relevant". This suggests that the majority of participants do not have a strong interest in the internet. On the other hand, the answers to the items related to burnout indicated a higher level compared to internet addiction. Most of the items were answered as "relevant".

The statistical analysis showed a significant and positive correlation between internet addiction and burnout, which was statistically significant $(r=.450, n=233 ; p<.05)$. This finding reveals that internet addiction has an impact on the burnout syndrome, and that the higher the level of internet addiction is the more intense the student experiences burnout.

Table 2

Findings of hierarchical regression for burnout

\begin{tabular}{|c|c|c|}
\hline Variables & Model-1 & Model-2 \\
\hline Gender & $-0,008$ & $-0,028$ \\
\hline Educational Level & $-0,039$ & $-0,046$ \\
\hline Internet Addiction & & $0,375^{* * *}$ \\
\hline$R$ & 0,033 & 0,469 \\
\hline$R^{2}$ & 0,001 & 0,220 \\
\hline Adapted $R^{2}$ & $-0,008$ & 0,210 \\
\hline$F$ & 0,122 & 21,558 \\
\hline$\Delta R^{2}$ & $-0,001$ & 0,219 \\
\hline
\end{tabular}

In addition to the correlation analysis, the variables internet addiction and burnout were explored through a hierarchical regression test in order to reveal if the variable burnout explains a statistically significant amount of variance in the variable internet addiction after accounting for gender and educational level (Table 2 ). The results of the test were statistically significant $\left[F_{(1,229)}=\right.$ $21,558 ; p<0,001]$. As presented in Table 2, the $\mathrm{R}^{2}$ level was identified as 0.220 , which indicates that $22 \%$ of burnout can be explained by internet addiction. Furthermore, the analysis of the Beta coefficient showed that the level of burnout increased by 0.38 units when the level of internet 
addiction increased by one unit $(p<0,001)$. Based on the results of these analyses, the first hypothesis was confirmed.

In order to provide statistically verified research conclusions, it is essential to disprove the existence of multicollinearity which is done through the analysis of Tolerance and VIF rates of the dependent variable (internet addiction) (Büyüköztürk, 2009). The analysis showed that the Tolerance rate was bigger than $0.20(0.999>0.20)$, and the VIF rate was lower than $10(1.001<10)$, which led to the conclusion that the variable internet addiction did not have multicollinearity.

Table 3

The moderating role of educational level between internet addiction and burnout

\begin{tabular}{lll}
\hline Variables & Model-1 & Model-2 \\
\hline Internet Addiction & 0,374 & $0,374^{* * *}$ \\
\hline Educational Level & $-0,046$ & $-0,046$ \\
\hline IA x EL & & 0,023 \\
\hline$R$ & 0,469 & 0,470 \\
\hline$R^{2}$ & 0,220 & 0,221 \\
\hline Adapted $R^{2}$ & 0,213 & 0,211 \\
\hline$F$ & 32,392 & 21,677 \\
\hline$\Delta R^{2}$ & 0,220 & 0,001 \\
\hline${ }^{*} p<0.05 ;{ }^{* *} p<0.01 ;{ }^{* * *} p<0.001$ & &
\end{tabular}

The hierarchical regression results revealed that internet addiction had a significant impact in the first regression model $\left[F_{(2,230)}=32,392 ; p<0,001\right]$ (Table 3). On the other hand, the change in $R^{2}$ was not found significant in the second model $\left[F_{(1,229)}=21,677 ; p>0,05\right]$. Upon the inclusion of all variables, it was found that internet addiction had a significant effect on emotional burnout $\left(\beta=0,374^{* * *}, p<0.001\right)$ and that educational level had no significant effect on emotional burnout $(\beta=-$ $0,046, p>0.05)$. Furthermore, it was revealed that internet addiction and educational level had no significant transactional effect on emotional burnout $(\beta=0,023, p>0.05)$.

The finding of a non-significant multiplicative result of the correlation between internet addiction and educational level leads to the conclusion that these variables have no interaction effect on emotional burnout; in other words, that educational level does not have a moderating role. Therefore, the second hypothesis is rejected.

In order to eliminate the factor of multicollinearity, the level of Tolerance and VIF of the independent variable (internet addiction $X$ educational level) were examined. The Tolerance value being higher than $0.20(1.000>0.20)$ and the VIF value being lower than $10(1,000<10)$ pointed to the conclusion that the variable did not have multicollinearity.

Table 4.

The moderating role of gender between internet addiction and burnout

\begin{tabular}{lll}
\hline Variables & Model-1 & Model-2 \\
\hline Internet Addiction & 0.374 & $0.376^{* * *}$ \\
Gender & -0.013 & -0.012 \\
IA x G & & 0.035 \\
$R$ & 0.468 & 0.471 \\
$R^{2}$ & 0.219 & 0.222 \\
Düzeltilmiş $R^{2}$ & 0.212 & 0.212 \\
$F$ & 32.206 & 21.796
\end{tabular}


${ }^{*} p<0.05 ;{ }^{* *} p<0.01 ;{ }^{* * *} p<0.001$

As shown in Table 4, the hierarchical regression results presented a significant effect of internet addiction in the first regression model $\left[F_{(2,230)}=32.206 ; p<0.001\right]$. On the contrary, the change in $R^{2}$ was not found significant in the second model $\left[F_{(1,229)}=21.796 ; p<0.05\right]$. Upon the inclusion of all variables, it was found that internet addiction and gender had no significant effect on emotional burnout $(\beta=0.035, \mathrm{p}>0.05)$.

The finding of a non-significant multiplicative result of the correlation between internet addiction and gender leads to the conclusion that these variables have no interaction effect on emotional burnout; in other words, that gender does not have a moderating role. Thus, the third hypothesis is rejected.

The factor multicollinearity of the independent variable (internet addiction $\mathrm{X}$ gender) was eliminated as the level of Tolerance and VIF was higher than $0.20(0.998>0.20)$ and lower than 10 $(1.002<10)$, respectively. Accordingly, the variable did not have multicollinearity.

\section{Discussion and Conclusion}

The primary goal of the study was to examine the relations between internet addiction and burnout of university students in Turkey. In addition, the role of gender and educational level between the two factors was analyzed. To achieve this goal, the "Skala zur Erfassung der Internetsucht" Internet Addiction Questionnaire (Hahn und Jerusalem, 2001) and the Maslach Burnout Inventory-SS were used. The findings of the study revealed a positive correlation between internet addiction and burnout; in order words, the level of internet addiction has an impact on the level of burnout and vice versa. This result is in accordance with Aro et al. (2017) who explored the excessive use of internet and school burnout of Finnish Adolescents. They also concluded that excessive internet use predicted burnout. In a similar vein, Şahin (2016) administered a study examining the relationship between internet addiction and life satisfaction in a Turkish setting, and he revealed a significant negative relation between internet addiction and life satisfaction; in other words, less internet addicted students have a lower level of burnout. These studies show that the present study is in consistency with the recent studies in the literature.

Additionally, it was found that gender and educational level do not have a moderating role in the correlation between internet addiction and burnout. This result is inconsistent with the studies of Mottram and Fleming (2009) and Randler et al. (2014) who found that males are more prone to the extensive use of internet than females. One of the reasons may be listed as the profile of the participants. The present study focused particularly on students who have a high chance of working in offices or in management as the future entrepreneurs, while the other two studies worked with students of other departments. Consistent with the present study, the study of Ainin et al. (2017) who explored internet addiction of adults working in offices stated no significant difference between internet addiction and gender. Considering that the participants of Ainin et al.'s study may be the future of the participants of the present study, the comparison of the results may indicate that gender maintains to have a minor role of gender in the level of internet addiction.

The last finding of the present study was that gender and educational level had no effect on the level of burnout. This finding is consistent with Breso, Salanova and Schaufeli (2007) who conducted a crosscultural study on the effect of demographic variables on burnout. They found no significant difference between female and male participants based on the level of burnout. Addis (2006) found that freshmen have a higher level of burnout than the other classes, but added that this difference is non-significant.

Based on the results obtained, some suggestions were proposed: (1) the study uncovered that internet addiction had an impact on the increase of emotional burnout. Therefore, more social activities should be organized at university and students should be motivated to join in. This way, the time spent in the internet during their free time may be reduced. (2) Seminars on the effective use and 
the harmful aspects of the internet could be given to students to raise awareness. (3) NGO's, such as Yeşilay could open new units related to internet addiction and run them actively. Thereby, not only products like alcohol and cigarettes, but also virtual products could be kept under control. (4) Despite some benefits of the internet use during class, students need to be aware when there is a real need to use it. Thus, school principals should work with teachers for precautions to limit internet use during class time. There is a need to add that these implications should be considered for both genders and all educational levels as the findings of the present study revealed that neither gender nor educational level has a moderating role on the relationship between internet addiction and emotional burnout, and that these variables have no impact on the rate of emotional burnout.

This study includes some limitations which should be considered. First, the study was conducted on university students studying Business and Administration. The group of participants of this study hinders the generalizability of the study to other students (secondary, high school). Second, the possibility that the participants might have altered their real thoughts and responded in line with the expectations of the surveyor can be considered as a limitation. Finally, with the study being cross sectional, the participants might have answered the items based on their momentary mood, instead of considering the items from a general point of view. 


\section{References}

Addis, R. S. (2006). Burnout among undergraduate athletic training students. Dissertation, California University. U.S.A

Akdağ, M., Yılmaz, B. S., Özhan, U., and Şan, İ. (2014). Üniversite Öğrencilerinin İnternet Bağımlılıklarının Çeşitli Değişkenler Açısından İncelenmesi (İnönü Üniversitesi Örneği), İnönü Üniversitesi Eğitim Fakültesi Dergisi, 15(1), 73-96

Anin, S., Jaafar, N. I., Ashraf, M., and Parveen, F. (2017). Exploring the Role of Dempgraphics and Psychological Variables in Internet Addiction. Social Science Computer Review, 35(6), 770780 .

Arı, G. S., Bal, E. Ç. (2008). Tükenmişlik kavramı: Birey ve örgütler açısından önemi. Yönetim ve Ekonomi: Celal Bayar Üniversitesi İktisadi ve İdari Bilimler Fakültesi Dergisi, 15(1), 131-148.

Avcı, D. K., Şahin, H. A. (2017). Relationship between Burnout Syndrome and Internet Addiction, and the Risk Factors in Healthcare Employees in a University Hospital, Konuralp Tip Dergisi, 9 (2), 1-8

Batem (2016). Internet ve Bilgisayar Bă̆ımlılı̆̆g. http://www.batem34.com (04.04.2016).

Bayraktar, F. ve Gün, Z. (2007). Incidence and correlates of internet usage among adolescents in North Cyprus. Cyberpsychology \& Behavior, 10; 191-197.

Çapri, B.; Gündüz, B. ve Gökçakan, Z. (2011). Maslach Tükenmişlik Envanteri-Öğrenci Formu (MTE-ÖF)'nun Türkçe'ye Uyarlaması: Geçerlik ve Güvenirlik Çalışması, Çukurova Üniversitesi Eğitim Fakültesi Dergisi. 40 (1), 134-147.

Freudenberger, H.J. (1974). "Staff Burn-Out”, Journal of Social Issues, Vol.30, Number 1, 159-165.

Girgin, G. (1995). "İlkokul Öğretmenlerinde Meslekten Tükenmişliğin Gelişsimini Etkileyen Değişkenlerin Analizi ve Bir Model Önerisi”, Yayınlanmamış doktora tezi, Dokuz Eylül Üniversitesi, İzmir.

Gündüz, B., Çapri, B., ve Gökçakan, Z. (2012). Üniversite Öğrencilerinin Tükenmişlik Düzeylerinin İncelenmesi, Dicle Üniversitesi, Ziya Gökalp Eğitim Fakültesi Dergisi, 19(2012), 38-55.

Hawi, N.S. (2012). Internet addiction among adolescents in Lebanon. Computers in Human Behavior, $28,1044-1053$.

Işı1klar, A. (2002). "Lise Dengi ve İlköğretim Okullarındaki Öğretmenlerin İş Doyumu, Tükenmişlik ve Empatik Eğilimleri Arasındaki İlişkilerin Bazl Değişkenlere Göre Incelenmesi”, Yayınlanmamış yüksek lisans tezi, İstanbul Üniversitesi, İstanbul.

Kır, İ., Sulak, Ş. (2014). Eğitim Fakültesi Öğrencilerinin İnternet Bağımlılık Düzeylerinin İncelenmesi, Elektronik Sosyal Bilimler Dergisi, 13 (51), 150-167

Lam L. T., Peng Z.W., Mai J.C., and Jing J. (2009). Factors associated with Internet addiction among adolescents. CyberPsychology \& Behavior; 12: 551-555.

Lee, S. (2009). "Problematic Internet Use among College Students: An Exploratory Survey Research Study". A dissertation at University of Texas at Austin.

Maslach, C. ve Jackson, S.E. (1981). The Measurement of Experienced Burnout. Journal of Occupational Behavior, 2, 99-113.

Maslach, C. (2003). Job Burnout: New Directions in Research and Intervention. Current Directions in Psychological Science, 12, 5, 189-192. 
Mottram, A. J., and Fleming, M. J. (2009). Extraversion, impulsivity, and online group membership as predictors of problematic internet use. CyberPsychology \& Behavior; 12, 3, doi: 10.1089/cpb.20070170.

Özdemir, H.Ö. (2017). Yöneticilerin otantik liderlik tarzlarının çalışanların sanal kaytarma ve sinizm davranışları üzerine etkileri, Nevşehir Hacı Bektaş Veli Üniversitesi Sosyal Bilimler Enstitüsü, İşletme Anabilim Dalı Doktora Tezi, Nevşehir.

Salmela-Aro, K., Upadyaya, K., Hakkarainen, K., Lonka, K., and Alho, K. (2017). The dark side of internet use: two longitudinal studies of excessive internet use, depressive symptoms, school burnout and engagement among Finnish early and late adolescents. Journal of youth and adolescence, 46(2), 343-357.

Subrahmanyam, K. ve Lin, G. (2007). Adolescents on the net: Internet use and well-being. Adolescence, 42, 659-677

Sucuoğlu, B. ve Kuloğlu, N. (1996). Özürlü Çocuklarla Çalışan Öğretmenlerde Tükenmişliğin Değerlendirilmesi, Türk Psikoloji Dergisi, 10 (36), 44-60.

Schaufeli, W. B., Martinez, I., Marques-Pinto, A., Salanova, M., and Bakker, A. (2002). Burnout and Engagement in University Students: A cross-national study. Journal of CrossCultural Studies, $33,464-481$.

Şahin, C. (2016). Examination of the Relationship between Life Satisfaction Level and Internet Addiction of the Students in Guidance and Psychological Counseling Department. International Journal of Contemporary Educational Studies, 2(1), 1-13.

Şahin, C., Korkmaz, Ö. (2011). İnternet Bağımlılığı Ölçeğinin Türkçeye Uyarlanması, Selçuk Üniversitesi Ahmet Keleşoğlu Eğitim Fakültesi Dergisi, 32, 101-115

Şahin, C., Aydın, D., Balay, R. (2016). Eğitim Fakültesi Öğrencilerinin Eğitsel İnternet Kullanımı ile İnternet Bağımlılıklarının İncelenmesi, Ahi Evran Üniversitesi Kırşehir Eğitim Fakültesi Dergisi (KEFAD) 17(1), 481-497

Tsitsika, A., Janikian, M. Schoenmakers, T. M., Tzavela, E. C., Olafsson, K., Wojcik, S., Richardson, C. (2014). Internet addictive behavior in adolescence: A cross-sectional study in seven European countries. CyberPsychology, Behavior, and Social Networking, 17, 528-535.

Turan, R.T. (2015). Başkent Üniversitesi öğrencilerinde internet bağımlılı̆̆ sıklı̆̆ ve ilişskili faktörler. Başkent Üniversitesi Tıp Fakültesi Aile Hekimliği Anabilim Dalı, Uzmanlık Tezi, Ankara

Tümkaya, S. (1996). Öğretmenlerdeki Tükenmişlik Görülen Psikolojik Belirtiler ve Başa Çıkma Davranışları, Yayımlanmamış doktora tezi, Çukurova Üniversitesi, Adana.

Yang, H. J., and Cheng, K. F. (2005). An investigation the factors affecting MIS student burn-out in technical-vocational college. Computers in Human Behavior, 21, 917-932.

Zhang, Y., Gan, Y., and Cham, H. (2005). The reliability and validity of MBI-SS and academic characteristics affecting burnout. Chinese Journal of Clinical Psychology, 13, 383-385. 


\section{Genişletilmiş Özet}

\section{Giriş}

Günümüzde İnternet, kolay erişilebilme ve etkileşim sağlama özelliğiyle insanların bilgiyi edinirken ve paylaşırken hızlı ve kolay yapabilmesine olanak sağlayan haberleşme, ticaret yapma, bankacılık hizmetlerinden yararlanma, eğlenceli vakit geçirme vb. gibi faaliyetleri yerine getirmemize vesile bir kaynak haline gelmiştir. Bu özelliği sayesinde internet tüm insanlığın ilgisini çeken, çağımızdaki en önemli teknolojik gelişmelerinden birisi olmuştur. Sunmuş olduğu güzel imkânlardan dolayı özellikle gençlerin hayatlarının bir parçası olmuştur.

İnternet bağımlılı̆̆ı terimini ilk kullanan kişi Goldberg (1996) "Ruhsal Bozuklukların Tanımsal ve sayısal El Kitabı" eserinde internet bağımlılı̆̆ 1 için göstergeler geliştirmiştir (Eroğlu ve Bayraktar, 2017). İnsanların sosyalleşme gereksinimi internet bağımlılığının önemli bir nedeni olarak gözükmektedir. Kişilerin gerçek olduklarından kendilerini daha farklı göstermek istemeleri, düşüncelerini daha kolay paylaşabilmeleri gibi hususlar da internet bağımlılığının nedenleri arasında sayılabilir (Cengizhan, 2005; Eroğlu ve Bayraktar, 2017).

Günümüzde teknolojinin gelişmesine bağlı olarak yeni teknolojik rahatsılıklar görülmektedir. İnternet bağımlılı̆̆ da bunlardan birisidir. İnternet bağımlısı olan kişilerin sayısı her geçen gün artmaktadır. Bunun nedeni olarak ta internetin sosyal hayattaki avantajlı özelliklerinin bulunması gösterilebilir. Birçok kişi gerçek dünyada bulamadığı tutkularını sanal dünyada yaşamaktadır (Batem, 2016). İnternet bağımlılığı dünyada olduğu gibi Türkiye'de de ciddi bir sorun haline gelmiş̧; bu sebepten dolayı 2012 yılında Bakırköy Ruh ve Sinir Hastalıkları Hastanesinde internet bağımlılığ polikliniği kurulmuştur (Özdemir, 2017).

Tükenmişlik konusunda birbirine yakın bazı tanımlar yer almaktadır. Freudenberger (1974) tükenmişliği, "başarısız olma, yıpranma, aşırı yüklenme sonucu güç ve enerji kaybı veya karşılanamayan istekler sonucu bireyin iç kaynaklarında tükenme durumu" olarak tanımlamaktadır (aktaran Arı ve Bal, 2008). Maslach'a (2003) göre tükenmişlik, işyerindeki stres artırıcı unsurlara karşı bir tepki olarak uzun sürede ortaya çıkan psikolojik bir sendromdur. Tükenmişlik kavramı, duygusal tükenme, duyarsızlaşma ve kişisel başarıda azalma hissi olarak üç alt boyuttan oluşmaktadır (Maslach ve Jackson, 1981).

İnternet bağımlılı̆g 1 ve duygusal tükenmişlik arasındaki çalışmalar incelendiğinde; Avci ve Şahin (2017) yaptıkları çalışmalarda tükenmişliğin alt boyutları ile internet bağımlılı̆̆ 1 arasında anlamlı bir ilişki bulmuşlardır. Selmela-Aro ve arkadaşları yaptıkları çalışmada (2017) gençler arasında aşırı internet kullanımının okul tükenmişliğine neden olacağının ve depresif semptomların gelişebileceğini belirtmişlerdir.

Yapılmış çalışmalar incelendiğinde cinsiyet ile internet bağl1lı̆̆ açısından çok farklı bulguların olduğu görülmektedir. Literatürde internet bağımlılı̆̆ ile cinsiyet arasında anlamlı fark saptanamayan çalışmalara rastlanmıştır. Elde edilen bulgulara benzer olarak cinsiyetler arasında fark bulunmadığını gösteren çalışmalar vardır (Turan, 2015; Lam vd., 2009; Subrahmanyam ve Lin, 2007; Bayraktar ve Gün, 2007). Şahin vd., (2016) yaptıkları çalışmada; kız öğrencilerin internet bağımlılığı puanını erkek öğrencilerinin puanından daha yüksek bulmuşlardır. Yapılan istatistiksel analiz sonucunda kız öğrenciler ile erkek öğrencilerinin internet bağımlılığı puanları arasındaki farkın anlamlı olmadığı sonucunu bulmuşlardır. Akdağ vd., (2014) ve Kır ve Sulak (2014) ise cinsiyet faktörünün internet bağımlılığın önemli bir belirleyicisi olduğunu ortaya koymuşlardır. Araştırmalarının sonuçlarına göre; erkek öğrencilerin kızlardan daha fazla internet bağımlısı oldukları sonucunu tespit etmişlerdir.

Yapılmış çalışmalar incelendiğinde cinsiyet ile tükenmişlik arasındaki ilişkiler açısından çok farklı bulguların olduğu görülmektedir. Literatürdeki çalışmalar incelendiğinde (Sucuoğlu ve Kuloğlu, 1996) ve (Işıklar, 2002) çalışmalarında cinsiyetin tükenmişlik üzerinde bir etkisinin olmadığ1 sonucunu bulmuşlardır. Yine literatürde erkek öğrencilerin daha tükenmiş olduğu yönünde çalışmalar 
(Girgin, 1995); (Tümkaya, 1996) ile kız öğrencilerin daha tükenmiş olduğu yönünde çalışmalar da (Gündüz vd., 2012) mevcuttur.

Şahin vd. (2016) yaptıkları çalışmada; sınıf düzeyine göre birinci sınıf öğrencilerin internet bağımlılığı puanını dördüncü sınıf öğrencilerinin puanından daha yüksek bulmuşlardır. Her ne kadar yapılan istatistiksel analiz sonucunda birinci sınıf öğrencileri ile dördüncü sınıf öğrencilerinin internet bağımlılığı puanları arasında fark olsa da bu farkın anlamlı olmadığını saptanmışlardır.

\section{Yöntem}

Araştırmanın verileri bir Türk devlet üniversitesinde İktisadi ve İdari Bilimler Fakültesi İşletme bölümü ve Sosyal Bilimler Meslek Yüksekokulu İşletme programlarında öğrenim gören 233 öğrenciden toplanmıştır. Araştırmada veri toplama aracı olarak; Hahn ve Jerusalem (2001) tarafindan tasarlanan ve orijinal adı "Skala zur Erfassung der Internetsucht" olan ve Şahin ve Korkmaz (2011) tarafından Türkçeye uyarlaması yapılan internet bağımlılığı ölçeği ve Schaufeli ve ark. (2002) tarafindan geliştirilen ve Türkçe uyarlaması Çapri, Gündüz ve Gökçakan (2011) tarafindan yapılan Maslach Tükenmişlik Envanteri-Öğrenci Formu (MTE-ÖF) kullanılmıştır. Verilerin analizinde SPSS 22 istatistiksel programı kullanılmıştır.

\section{Bulgular}

Çalışmanın sonuçlarına göre; internet bağımlılığı ile tükenmişlik arasında pozitif yönlü bir ilişki olduğu; bu ilişkide cinsiyet ve öğrenim düzeyi faktörlerinin düzenleyicilik rolünün olmadığ1 tespit edilmiştir. Araştırma bulguları yorumlanmış ve daha sonra gerçekleştirilecek araştırmalara yönelik öneriler geliştirilmiştir.

\section{Sonuç ve Öneriler}

Çalışmada elde edilen sonuçlar, uygulama açısından da bazı öneriler getirmektedir: (1) İnternet bağımlılığının duygusal olarak tükenmişliği arttırdığı sonucuna istinaden; Okullarda sosyal aktivitelere öğrencilerin daha fazla katılımı sağlanabilir. Böylece öğrencilerin boş zamanlarda internette zaman geçirme süreleri azaltılabilir. (2) İnternetin etkili kullanımı ve zararlı yönlerinin neler olduğu hakkında bu işin uzmanları tarafından gerekli eğitimler verilebilir. Böylece internetin zararları hakkında farkındalık oluşturulabilir. (3) Yeşilay vb. gibi sivil toplum kuruluşlarının bu konu ile ilgili birimler kurarak aktif bir şekilde çalıştırması sağlanabilir. Böylece sadece alkol ve sigara gibi ürünlerin değil sanal ürünlerin de kontrolü sağlanmış olabilir. (4) İnternet bağımlılığı ile duygusal tükenmişlik arasındaki ilişkide öğrenim görülen düzeyin ve cinsiyetin düzenleyicilik rolünün olmaması sonucu; duygusal tükenmişliğin cinsiyete ve öğrenim düzeyine bağlı olmadığı dolayısı ile alınacak önlemlerin her iki cinsiyette ve her öğrenim düzeyinde geçerli olabileceği sonucunu doğurur. (5) İnternet kullanımının yararları bilinmesine rağmen okul yöneticileri tarafından sınıf içerisinde telefon kullanımını yasaklayıcı önlemlerin alınması gerekmektedir.

$\mathrm{Bu}$ çalışmanın bazı kısıtları da bulunmaktadır. İlk kısıtı araştırmanın örneklemi oluşturmaktadır. Bu çalışma sadece üniversitede öğrenim gören öğrencilere uygulanmış olup diğer düzeylerdeki öğrencilere (lise öğrencileri) uygulanabilirliği açısından bir kısıt oluşturabilir. Ortak yöntem varyansı ise bir diğer kısıtımızı oluşturmaktadır. Bir başka değişle denekler vermiş oldukları cevapların hocalarının eline geçme ihtimaline karşı var olan durumu tam olarak yansıtmamış olabilirler. Bununla birlikte araştırmamızın kesitsel olması deneklerin o anki ruh hali ve içinde bulundukları duruma göre değerlendirme yapmalarına ve genel durumu göz ardı etmelerine sebep olmuş olabilir. 